\title{
Pucciniastrum minimum is the causal agent of rust on blueberries in New Zealand
}

\author{
Mahajabeen Padamsee $^{1}$ (D) Eric H. C. McKenzie ${ }^{1}$ \\ Received: 19 February 2019 / Accepted: 24 July 2019 / Published online: 2 August 2019 \\ (C) Australasian Plant Pathology Society Inc. 2019
}

\begin{abstract}
The causal agent of rust on blueberries in New Zealand was determined by molecular and morphological analyses as Pucciniastrum minimum rather than Naohidemyces vacciniorum as first reported in 2004.
\end{abstract}

Keywords Blueberry $\cdot$ Pucciniales $\cdot$ Rust fungi $\cdot$ Thekopsora minima $\cdot$ Vaccinium

Three rust fungi were recognised by Sato et al. (1993) on blueberry plants (Vaccinium spp.); Pucciniastrum minimum (as Thekopsora minima) and two species which they placed in a new genus, Naohidemyces. Of the latter two species, Naohidemyces fujisanensis is restricted to Japan, but $N$. vacciniorum (= Melampsora vacciniorum) (Liang and Kakishima 2011) has a much wider distribution in North America, Europe and Japan. In 1980 and again in 1981, a rust identified as P. vaccinii was found on Vaccinium vitis-idaea plants growing in quarantine in Auckland, New Zealand. The plants, which had been imported from Germany, were destroyed.

In 2004, a rust was found infecting blueberry plants in an orchard in the Waikato region, North Island of New Zealand and was deposited in the New Zealand Fungarium with the accession number PDD 78424. Only urediniospores were observed and this specimen was identified as Naohidemyces vacciniorum (Anonymous 2006).

A recent publication (McTaggart et al. 2013) demonstrated that Pucciniastrum minimum (as Thekopsora minima) caused a rust on Vaccinium corymbosum in Queensland and New South Wales

Mahajabeen Padamsee

padamseem@landcareresearch.co.nz

1 Manaaki Whenua Landcare Research, 231 Morrin Road, St Johns, Auckland 1072, New Zealand in Australia, which prompted a re-examination of the New Zealand collections of rust fungi on blueberries. DNA from two recent collections (PDD 104137 and PDD 102321) was extracted and the $28 \mathrm{~S}$ region (nuLSU) was amplified according to the protocol outlined in Padamsee and McKenzie (2014). The LSU sequence of PDD 104137 and PDD 102321 (GenBank MK353419 and MK353420, respectively) had 99\% identity (with $100 \%$ query coverage) to Thekopsora minima (HM439777) in a BLAST search.

The newly generated sequences were aligned with five other sequences of $P$. minimum (as $T$. minima) deposited in GenBank and 21 sequences from the Padamsee and McKenzie (2014) study, which demonstrated that Thekopsora minima is recovered in a clade that encompasses Pucciniastrum sensu stricto and as a result the appropriate name for this species should be Pucciniastrum miminum. The dataset was analysed in GARLI (Zwickl 2006) using the GTR + $\Gamma+\mathrm{I}$ model of evolution and 1000 maximum likelihood bootstrap support (MLBS) values were generated in PhyML 3.0 (Guindon and Gascuel 2003). In the resulting phylogeny (Fig. 1), the generated sequences of the rust on blueberry in New Zealand were recovered in a highly-supported clade $(100 \%$ MLBS) with the other five sequences of $P$. minimum (as T. minima). The phylogeny also demonstrates that this fungal species is recovered in the moderately supported clade (69\% MLBS) with other Pucciniastrum species, including the generic type $P$. epilobii. 


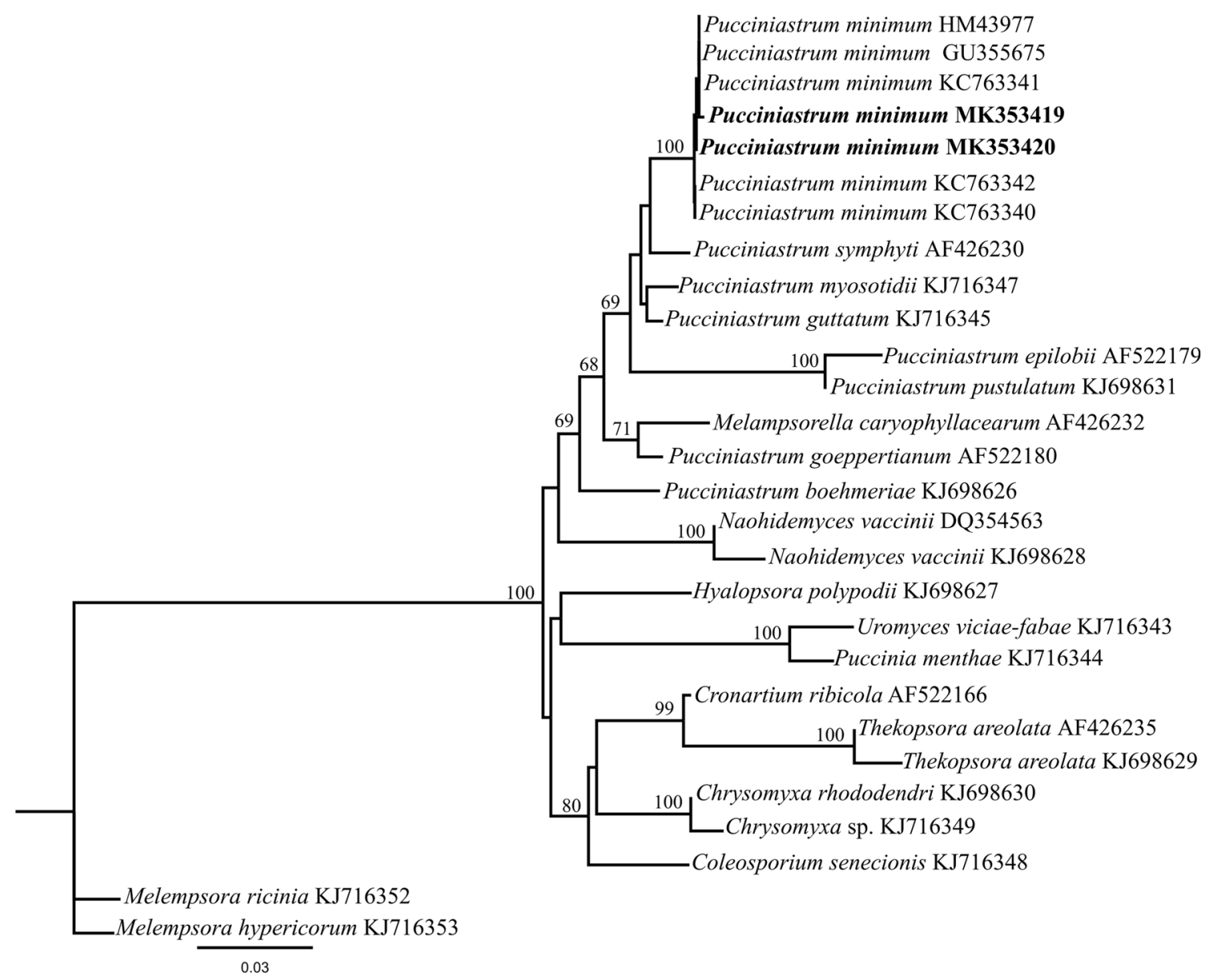

Fig. 1 Phylogram obtained from maximum likelihood analysis of nuclear LSU rDNA. Bootstrap support values (> 65\%) from a maximum likelihood search with 1000 replicates shown

The original 2004 specimen and several later collections were examined: on Vaccinium sp. 'Jersey', Auckland, Warkworth, Omaha, Jones Road, 5 Apr 2005, C.F. Hill (PDD 82858-II); on Vaccinium sp. 'Misty', Mt. Albert, 27 Nov 2014, P. Wilkie (PDD 105401-II); on Vaccinium sp., Waikato, Te Awamutu, Ngaroto Nurseries, 15 Jan 2004 , S. Ganev (PDD 78424-II); on Vaccinium sp., SH 1B bypass of Hamilton, south of crossing east coast main trunk railway, 13 Jan 2012, E.H.C. McKenzie (PDD 102321-II), GenBank MK353419; on V. corymbosum, Mid Canterbury, West Melton, Weedons Ross Road, 22 Jan 2014, G. Logan (PDD 104137-II), GenBank MK353419. All specimens had the following morphology. Uredinia were hypophyllous, golden-yellow, scattered or 4-5 grouped on angular, veinlimited brown spots and a dark brown spot with a red border on the corresponding upper-leaf surface, uredinia circular, up to $0.25 \mathrm{~mm}$ diam., bullate, opening by a central pore, and becoming pulverulent (Fig. 2a). Urediniospores were subglobose, ellipsoidal or obovoid, $15-21(-23) \times(12-) 13-15(-18)$ $\mu \mathrm{m}$ (mean $18.5 \times 14.1 \mu \mathrm{m})$, with yellow contents, and a wall $(0.5-) 1(-1.5) \mu \mathrm{m}$ thick, hyaline, and echinulate; germ pores were not seen (Fig. 2b).

Pucciniastrum minimum (as T. minima) has been recently recorded in South Africa (Mostert et al. 2010) and in Mexico (Rebollar-Alviter et al. 2011). Although it proved impossible to extract DNA from the rust on the blueberry plants imported to New Zealand from Germany in the 1980s, the known world distribution of $P$. minimum and Naohidemyces vacciniorum would suggest that it was $N$. vacciniorum. As those plants with their rust were destroyed, we may conclude that the only rust fungus present on blueberries in New Zealand currently is P. minimum. 


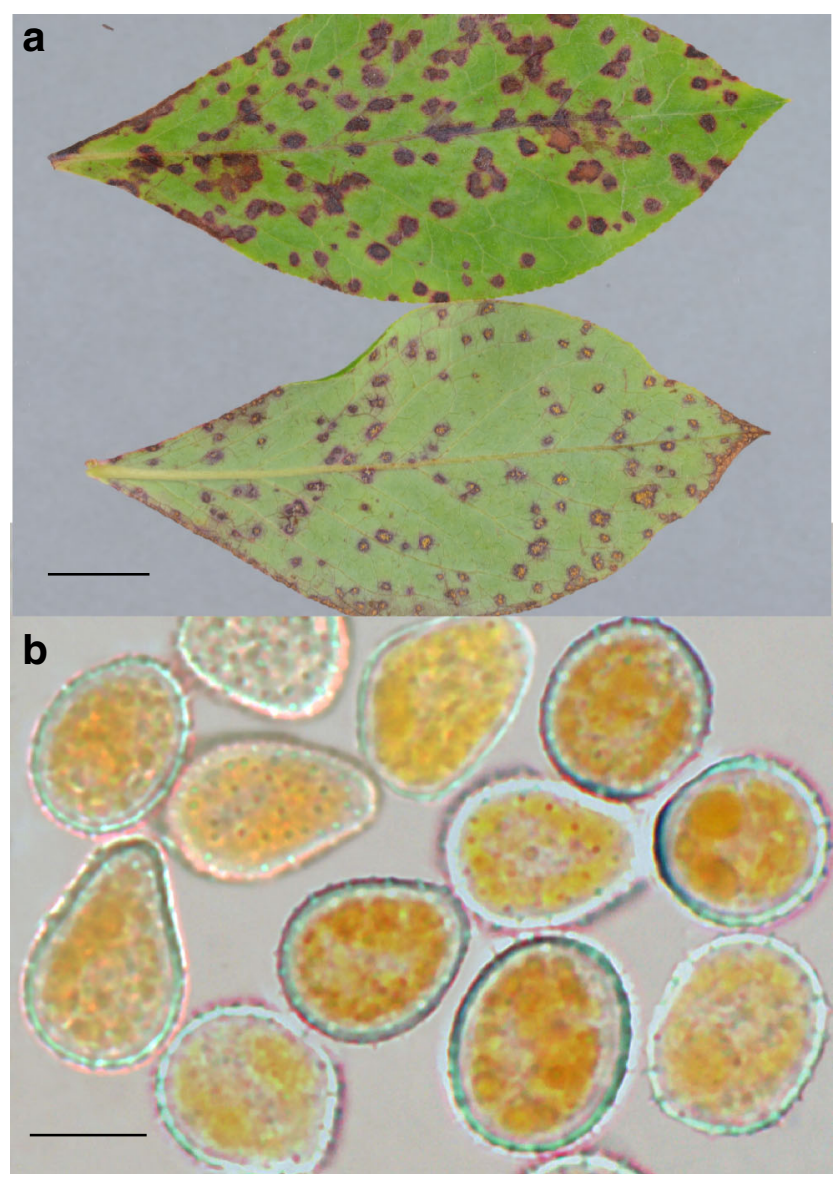

Fig. 2 Pucciniastrum minimum on Vaccinium corymbosum. a Abaxial and adaxial leaf symptoms; (b) Urediniospores. Scale $\mathrm{a}=5 \mathrm{~cm} ; \mathrm{b}=$ $10 \mu \mathrm{m}$

Acknowledgments This research was supported through the Manaaki Whenua Landcare Research Biota Portfolio, with funding from the Science and Innovation Group of the New Zealand Ministry of Business, Innovation and Employment.

\section{References}

Anonymous (2006) Plant kingdom records 18/03/2006-05/05/2006. Biosecurity 68:30-31

Guindon S, Gascuel O (2003) A simple, fast, and accurate algorithm to estimate large phylogenies by maximum likelihood. Syst Biol 52: 696-704

Liang Y-M, Kakishima M (2011) Pucciniastrum enkianthi nom. nov., a replacement name for $P$. hakkodaense. Mycotaxon 115:505-506

McTaggart A, Geering A, Shivas R (2013) Thekopsora minima causes blueberry rust in South-Eastern Queensland and northern New South Wales. Aust Plant Dis Notes 8:81-83

Mostert L, Bester W, Jensen T, Coertze S, Van Hoorn A, Le Roux J, Retief E, Wood A, Aime M (2010) First report of leaf rust of blueberry caused by Thekopsora minima on Vaccinium corymbosum in the Western cape. South Africa Plant Disease 94:478-478

Padamsee M, McKenzie EHC (2014) A new species of rust fungus on the New Zealand endemic plant, Myosotidium, from the isolated Chatham Islands. Phytotaxa 174:223-230

Rebollar-Alviter A, Minnis A, Dixon L, Castlebury L, Ramírez-Mendoza M, Silva-Rojas H, Valdovinos-Ponce G (2011) First report of leaf rust of blueberry caused by Thekopsora minima in Mexico. Plant Dis 95:772-772

Sato S, Katsuya K, Hiratsuka Y (1993) Morphology, taxonomy and nomenclature of Tsuga-Ericaceae rusts. Trans Mycol Soc Jpn 34:47-62

Zwickl D (2006) GARLI - genetic algorithm for rapid likelihood inference. See http://www.bio utexas edu/faculty/antisense/garli/Garli html 